\author{
Małgorzata Kożuch \\ Uniwersytet Jagielloński \\ (D) https://orcid.org/0000-0002-5559-2555 \\ https://doi.org/10.15633/9788374386753.07
}

\title{
Uniwersytet jako organizacja ucząca się w obszarze rozwiązywania konfliktów
}

Prezentowany artykuł jest propozycją adaptacji wycinka dorobku nauki o zarządzaniu, nauki prawa oraz socjologii i psychologii do struktury, jaką jest uniwersytet. Jest to koncepcja autorki, która kapitalizuje posiadane doświadczenie i refleksję nad sposobami rozwiązywania konfliktów do realiów działania uniwersytetu. Teza, którą stawia autorka, brzmi: uniwersytet jest strukturą, która jest zdolna implementować modele działania organizacji uczącej się w obszarze rozwiązywania konfliktów ${ }^{1}$.

Bazą dla budowanej koncepcji uniwersytetu jako organizacji uczącej się w obszarze rozwiązywania konfliktów jest wiedza i doświadczenie prawnicze $^{2}$ oraz doświadczenie w rozwiązywaniu konfliktów ${ }^{3}$. Proponowane wnioski oparte są na zastosowaniu koncepcji organizacji uczącej się ${ }^{4}$ do uniwersytetu, ze specyfikacją obszaru rozwiązywania konfliktów. Wnioski

1 Inspiracją dla postawienia takiej tezy były badania i wyciągnięte na ich podstawie wnioski przedstawione w: K.S. Cameron, R.E. Quinn, Kultura organizacyjna - diagnoza i zmiana. Model wartości konkurujących, wydanie 2, Wolters Kluwer, Warszawa 2015. Znaczenie miały także: K. Obłój, Praktyka strategii firmy. Jak zarządzaćprzeszłościa, radzić sobie z teraźniejszościa i tworzyćprzyszłość, Wydawnictwo Poltex, Warszawa 2020; Ł. Sułkowski, M. Bednarek, A. Parkers, Kulturowa zmienność systemów zarządzania, Difin, Warszawa 2016. Wstępna koncepcja przedstawiona była podczas polsko-niemieckiego seminarium: 14th International Colloquium of the Research Group on Mediation from 13th to 15th June 2019 in Cracow (Poland) w ramach struktur Forschungsgruppe Mediation.

2 Autorka jest pracownikiem naukowym Uniwersytetu Jagiellońskiego w Katedrze Prawa Europejskiego, doktorem nauk prawnych ze specjalizacją w prawie międzynarodowym i praktykującym od 20 lat adwokatem.

3 Autorka jest mediatorem Prokuratorii Generalnej Rzeczpospolitej Polskiej, Centrum Mediacji Naczelnej Rady Adwokackiej oraz Centrum Mediacji i Arbitrażu Izby Przemysłowo Handlowej w Krakowie, prowadzi stałą praktykę w obszarze mediacji gospodarczej.

4 Por. P.M. Senge, A. Kleiner, Ch. Roberts, R. B. Ross, B. J. Smith. Piata dyscyplina. Materiaty dla praktyka, Wolters Kluwer, Warszawa 2013. 
uwzględniają wyniki badań przeprowadzonych przez grupę badawczą ${ }^{5}$ pod kierownictwem autorki wśród pracowników i studentów Uniwersytetu Jagiellońskiego, Uniwersytetu Warszawskiego oraz Uniwersytetu Mikołaja Kopernika w Toruniu, przeprowadzonych w 2019 roku. Istotne było także uwzględnienie wniosków płynących z raportów ombudsmanów uniwersyteckich składanych w ramach współpracy w sieci ENOHE ${ }^{6}$.

\section{Spojrzenie całościowe na uniwersytet}

Doświadczenie podpowiada, że zainicjowanie zmian na uniwersytecie jest stosunkowo proste. Znacznie jednak trudniej jest doprowadzić do trwałych i efektywnych wyników ${ }^{7}$. Uczestnicy innowacji niejednokrotnie mają poczucie walki ze zjawiskami stanowiącymi element status quo, zwłaszcza gdy uniwersytet może poszczycić się wielowiekową tradycją. Myślenie strategiczne o zmianach wymaga więc nie tylko opracowania planu realizacji inicjatywy, ale nade wszystko rozważenia, czy pewne elementy nie sięgają głębiej, czy dotyczą postaw i przekonań osób tworzących aktualną, żywą tkankę uniwersytetu. Co więcej, planując strategicznie, należy uwzględniać dynamikę procesu $z_{\text {zmian }}^{8}$. Niektóre elementy zmiany przynoszą bezpośrednie efekty w krótkim terminie, inne widoczne są po dłuższym okresie ${ }^{9}$. W międzyczasie mogą pojawić się „efekty uboczne” zmian, wygenerowane mogą zostać postawy obronne, które są naturalnym elementem procesu. Wymagają one jednak elastyczności i wrażliwego monitoringu, aby innowacje zamierzone przez twórców i realizatorów projektu nie tylko zmierzały do projektowanego celu, ale także zwiększały warstwę dobra towarzszącego działalności uniwersyteckiej ${ }^{10}$.

5 Zespół badawczy składał się z prof. dr. hab. Arkadiusza Sobczyka (prawo UJ), dr. hab. Mariusza Furgała (psychiatria UJ), dr. Mateusza Pękali (socjologia i prawo Akademia Ignatianum w Krakowie), dr Małgorzaty Kożuch (prawo UJ) - kierownika projektu. Opis i wyniki badań są prezentowane w zbiorze.

6 Rob Behrens Raport ENOHE European Network of Ombudsmen in Higher Education A Compatarive Study, 2017.

7 Natemat metod wprowadzania zmian zobacz:E.H. Schein, P. A. Schein, Potęgarelacjiwzarzadzaniu. O trudnej sztuce bycia pokornym liderem, Wydawnictwo Naukowe PWN, Warszawa 2019; A. M. Zawadzka, Psychologia zarzadzania w organizacji, Wydawnictwo Naukowe PWN, Warszawa 2010.

8 Por. M. Loeffler, AGILE. Retrospektywy w zarządzaniu standardami, Wydawnictwo Helion SA, Gliwice 2018,

9 Na temat metod oceny: S. Nikodemska, Assessment Development Center. Projektowanie procesu i narzędzi oceny, INFOR, Warszawa 2018.

10 Na temat „technicznych” aspektów podejmowania decyzji: A. PrusakP. Stefanów, AHP-analityczny proces hierarchiczny. Budowa i analiza modeli decyzyjnych krokpo kroku, C. H. Beck, Warszawa 2014. 
Uniwersytet oparty jest na tożsamości. Według teorii tożsamości Daniela L. Shapiro (odnoszącej się do osób fizycznych) na tożsamość składają się przekonania, obyczaje, przynależność, wartości i ważne emocjonalne doświadczenie ${ }^{11}$. Przenosząc te elementy na organizację, jaką jest uniwersytet, możemy zidentyfikować:

- przekonania - konkretne idee i poglądy, które uniwersytet przyjmuje i propaguje;

- obyczaje - rytuały i tradycje mające znaczenie, na przykład święta, stroje, regularne sesje, sposób podejmowania decyzji;

- przynależność - lojalność odczuwana wobec jednostki bądź grupy, na przykład emerytowanych profesorów, pracowników naukowych, poczucie związku z poprzednikami, troska o kolejne pokolenia;

- wartości - wzorce, którymi się kieruje uniwersytet, i sztandarowe ideały, w które wierzy, często wyrażane jednym słowem, takim jak: prawda, godność, tolerancja lub wolność;

- emocjonalnie ważne doświadczenia - pozytywne lub negatywne wydarzenia, które kształtują tradycję uniwersytetu. Obejmują wszystko, począwszy od dnia założenia po moment aktualny.

\section{Uniwersytet - organizacja ucząca się}

Pierwszym filarem organizacji uczącej się jest interakcja zachodząca między trzema elementami:

- postawami i przekonaniami,

- kwalifikacjami i zdolnościami,

- świadomością i wrażliwością.

Prawidłowy przebieg tego procesu przynosi efekt tzw. głębokiego uczenia się.

Podkreślić należy, że niezależnie od jakiego elementu cyklu rozpocznie się zmiany, to ich wprowadzenie powoduje cyrkularną przemianę organizacji. Przykładowo, rozpoczynając realizację inicjatywy od zaoferowania nabycia kwalifikacji i podniesienia umiejętności miękkich w zakresie

11 Szerzej: D.L. Shapiro, Negocjuj nienegocjowalne. Jak rozwiązywać konflikty podszyte emocjami?, Harvard Business Review Polska 2019. 
rozwiązywania konfliktów, można doprowadzić do zmiany świadomości i wrażliwości ${ }^{12}$. Zmiany w zakresie wrażliwości mogą wpływać na postawy, a docelowo także na przekonania ${ }^{13}$. W efekcie cyrkularny układ zależności powoduje, że powstaje tzw. obszar trwałej zmiany. W organizacji uczącej się kwalifikacje i zdolności grupowane są w trzy kategorie: aspiracje, refleksje/ rozmowy/autorefleksje, konceptualizacja. W zakresie aspiracji ważne jest podkreślenie, że chodzi o zmiany, które dyktowane są potrzebą osobistego „mistrzostwa”, uzyskiwania nowych kompetencji, których się nie ma, a które uważa się za ważne, ale nie zawsze konieczne. Nikt nie chce przecież być postrzegany jako osoba konfliktowa lub nie radząca sobie z konfliktami. Indywidualne pragnienie poczucia doskonałości (master of excellence) jest nośnikiem dla indywidualnego, długotrwałego zaangażowania oraz wartością dodaną projektu. Drugi element, czyli refleksja i rozmowa, ma nade wszystko służyć zbudowaniu poczucia uczestnictwa we wspólnym, ważnym dla uniwersytetu projekcie. Chodzi więc nie o sytuację „wygłaszania opinii” i wysłuchiwania innych opinii, ale o „świadectwo” - refleksję nad drobnymi sytuacjami podczas wprowadzania zmian ${ }^{14}$. Metoda małej narracji (story telling) pomaga uwspólnotowić doświadczenie, ale także ośmielić osoby niemające poczucia sprawczości, jak również cechujące się niezbyt wysokim poczuciem własnej wartości ${ }^{15}$. Trzeci z elementów - konceptualizacja - ma pomóc w dostrzeganiu przez uczestniczących w projekcie zmian w zakresie szerszych systemów i podsystemów. Umacnia to także budowanie własnych poglądów, a nie tylko powtarzanie cudzych, co jest wartością bezcenną w świecie akademickim. Nabycie umiejętności konceptualizacji pomaga w efekcie w budowaniu projektów nie tylko indywidualnych, ale także istotnych społecznie.

12 Por. W. Haman, J. Gut, Zrozumieć zespót. Fenomen matej grupy. Jak radzić sobie z trudnymi zrachowaniami zespotu, a zwłaszcza z narzekaniem i marudzeniem, Kontakt OSH Grupa Szkoleniowa 2019.

Por. S. Neale, I. Spencer-Arnell, L. Wilson, Coaching inteligencji emocjonalnej, Wolters Kluwer, Warszawa 2018.

14 Na temat trudniej sztuki przekazu oraz jego deformacji: M. Kaszowy, Strategie retoryczne, techniki komunikacyjno-poznawcze, błędy i sofizmaty, Wydawnictwo IFIS PAN, Warszawa 2015; J. Stelmach, B. Brożek, Negocjacje. Jak negocjować w sposób stuszny, skuteczny i ekonomicznie efektywny?, Copernicus Center Press. Kraków 2019; A. Nikolopoulos, Negotiating Strategically. One Versus All, Palgrave Macmillan Andreas Nikolopoulos 2011.

Na temat budowania opowieści narracyjnych: P. Tkaczyk, Narratologia, Wydawnictwo Naukowe PWN, Warszawa 2017. 
Rys. 1. Grafika obrazuje współzależność, jaka zachodzi pomiędzy trzema elementami: świadomością i wrażliwością, postawami i przekonaniami oraz kwalifikacjami i zdolnościami.

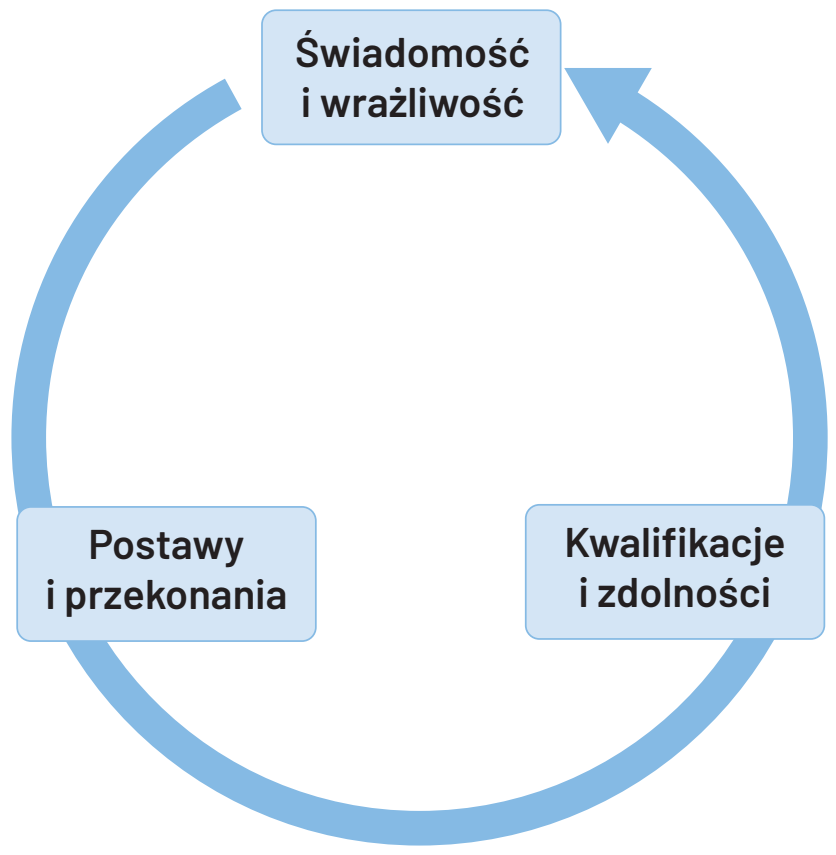

Rysunek zaczerpnięty z opisu koncepcji organizacji uczącej się, opracowanej przezPetera M. Senge, przypis z literatury.

Nabycie nowych kwalifikacji i zdolności skorelowane powinno być Z wprowadzeniem ich do praktyki codziennych zachowań. $Z$ upływem czasu nowa praktyka się utrwala, staje się automatyczna, a przez to prowadzi do rozwinięcia nowej wrażliwości. Przykładowo, reakcja opiekuna naukowego na emocjonalny post umieszczony przez studenta na Facebooku, Instagramie czy w dowolnym miejscu w sieci w pierwszym odruchu uruchamia mechanizm subiektywnej oceny, a nierzadko uznania, że mamy do czynienia z trudnym studentem. Dochodzi więc do oceny „przypisania winy” za sposób eksplikacji poglądów, a nawet zbudowania poczucia urażenia, jeżeli post kontekstowo może dotyczyć opiekuna naukowego lub uniwersytetu. Nowa świadomość i wrażliwość mogą natomiast spowodować uruchomienie 
procesu myślowego dotyczącego własnego sposobu postrzegania rzeczywistości czy sytuacji dającej impuls do wpisu, wzbudzenia poczucia wsłuchania się w to, co chciał wyrazić student, podjęcia próby ustalenia spojrzenia szerszego niż incydentalny wpis, a wręcz refleksji nad możliwym schematem działania. Innymi słowy, pojawia się nowy rodzaj „słuchania”, „widzenia”,

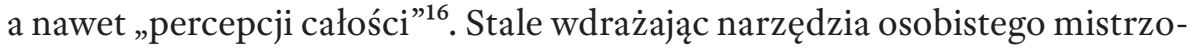
stwa, łatwiej można dostrzec, kiedy własne lub cudze działania są przejawem dobrze przemyślanych i celowo generowanych sygnałów, a kiedy wynikiem wyłącznie reakcji ad hoc, możliwej i łatwej do zrozumienia tylko kontekstowo, a poza kontekstem prawdopodobnie trudno akceptowalnej. Zbudowanie nowej świadomości pozwala na dostrzeżenie rozdźwięku, jaki może zachodzić między deklarowanymi przez organizację wartościami a istniejącą wewnętrzną kulturą organizacyjną. Na przykład głoszenie przez uniwersytet wartości, takich jak: tolerancja, transparentność czy godność, może stać w sprzeczności z elementarnymi przejawami zachowań członków korpusu akademickiego, którzy podejmują decyzję dotyczącą studenta bez uprzedniej rozmowy z zainteresowanym, komunikując mu ją przez osoby trzecie, a nawet pomijają potrzebę komunikacji, uznając, że to student ma interes uzyskiwaniu aktualnej informacji o jego statusie. Przekonanie opiekunów naukowych, że efektywność jest wynikiem wyłącznie stałej i pełnej kontroli sytuacji, nie umacnia poczucia podmiotowości u studentów. Ukrywanie (świadome lub nie) przez wykładowców niepewności, niekiedy niewiedzy, a czasem szerszego kontekstu zjawisk gasi w studentach poczucie potrzeby poszukiwania rozwiązań, a w efekcie obniża ich wiarę w siebie. W efekcie u studenta może wytworzyć się obraz wykładowcy jako aroganta, wykluczającego ze stanów rzeczywistych stany niepewności. Może to budować zbędne mury i niechęć. Przyjęcie przez wykładowcę postawy otwartej, wrażliwej, konfrontującej stale własne niedoskonałości z otaczająca rzeczywistością w poczuciu, że pewna doza niepewności istnieje, a błądzenie należy do rzeczy ludzkich, stwarza poczucie więzi, a w efekcie pozwala studentowi zbudować poczucie potrzeby trwania w postawie poznawczej, otwartej na odmienność, na prawdę i otaczającą rzeczywistość w poczuciu jedności z kadrą uniwersytecką. Eliminowana jest wówczas postawa konsumencka,

16 Na temat dochodzenia do „rozumienia” oraz rozwiązywania konfliktów: G. Friedman J. Himmelstein, Challenging Conflict. Mediation Through Understanding, ABA Section of Dispute Resolution 2008. 
roszczeniowa, oparta na relacjach transakcyjnych usługodawcy i usługobiorcy - pomiędzy studentem a uniwersytetem.

Drugim filarem organizacji uczącej się jest jej struktura. Uniwersytet jako struktura podlega schematowi podobnemu do każdej organizacji, mimo że ma znacznie szerszy profil interesariuszy niż większość organizacji komercyjnych czy nawet podmiotów publicznych.

Rys. 2. Grafika obrazuje obszar działania w ramach struktury organizacji, który objęty jest „aktywnymi” zmianami w ramach procesu uczenia się.

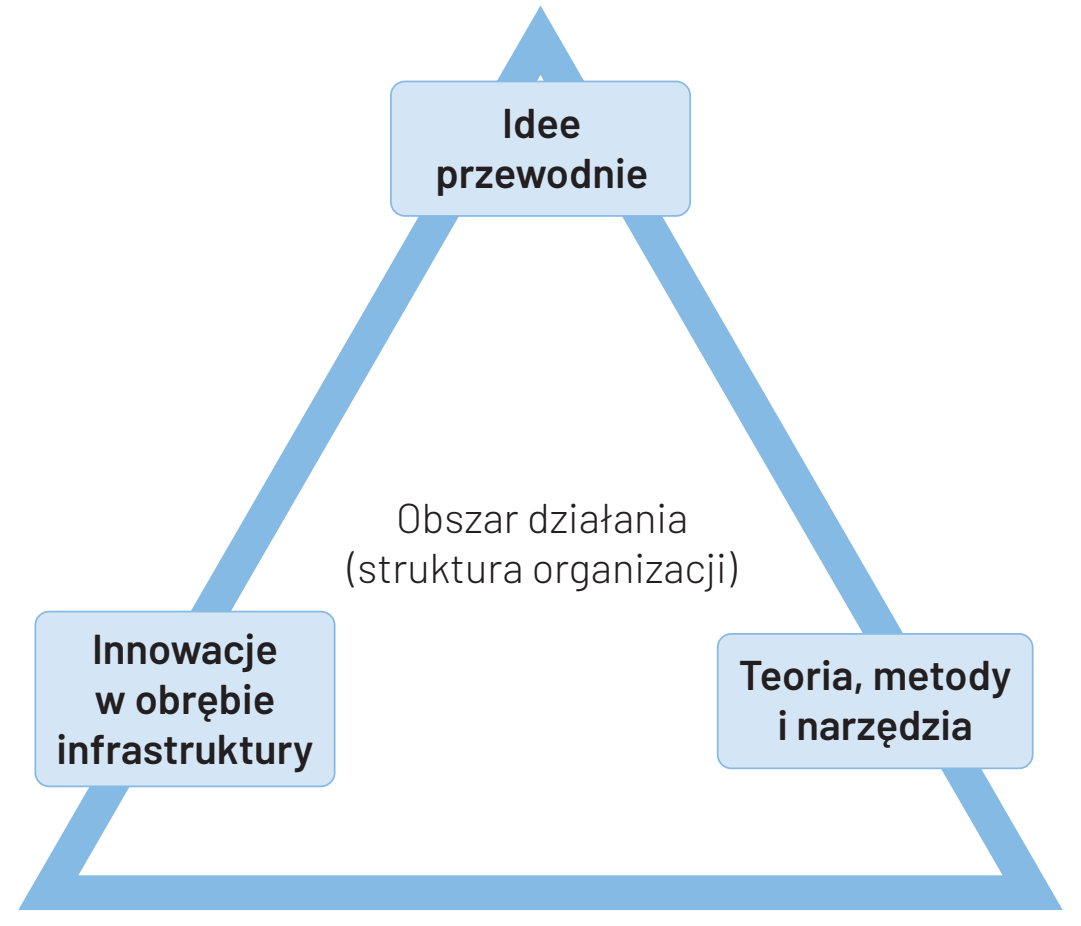

Dla określenia idei przewodnich uniwersytetu można odwołać się do jego tradycji. Można także położyć akcent na tkankę ludzką i odwołać się do teorii Abrahama Maslowa (piramida, u której podstaw są potrzeby fizjologiczne, następnie potrzeba bezpieczeństwa, wyżej potrzeba przynależności, bezpośrednio przed szczytem potrzeba szacunku, a na samej górze potrzeba samorealizacji). W tym kontekście stale wypada jednak pamiętać, że elementy te towarzyszą nie tylko kadrze naukowej, ale także studentom, doktorantom 
i pracownikom administracji. Ci ostatni niejednokrotnie zwracają uwagę, że czują się niedostrzeżeni, są raczej przedmiotem niż podmiotem, są odbiorcami komunikatów płynących od innych (najczęściej kadry naukowej uniwersytetu, studentów, doktorantów) bez poczucia podmiotowości. Taka sytuacja stoi w jawnej sprzeczności z głoszonymi przez wszystkie szkoły wyższe ideami humanitaryzmu, poszanowania godności, tolerancji, niedyskryminacji. W ramach rozważania idei przewodnich uniwersytetu jako organizacji uczącej się akcent winien być położony na trzy parametry. Po pierwsze prymat całości nad częścią ${ }^{17}$, po drugie wspólnotowość oraz po trzecie znaczenie sposobu komunikacji (twórcza siła języka). Idea uniwersytetu wymaga więc uwzględniania holistycznej i złożonej struktury osobowej i przedmiotowej, jaką tworzy uniwersytet, a nie zawężania jej tylko do warstwy nośnika wiedzy, badań czy osiągnięć na miarę XXI wieku. Istnieje potrzeba stałego aktualizowania poczucia, że uniwersytet jest schematem interakcji zachodzącej na płaszczyźnie wkładu intelektualnego w poznawanie świata, a schematami zachowań ludzkich dziejących się w obszarach administracyjnych, relacji poziomych i pionowych pracowników naukowych, relacjach koleżeńskich, relacjach w zespołach badawczych czy nawet interakcji z otoczeniem wytwarzanej przez jednostki, zarówno osobowości, jak i „miernoty”18. Peter Senge, odnosząc się do znaczenia języka, użył zwrotu: „Zapominając o twórczej sile języka szybko zaczynamy mylić mapy z samym terenem. Osiągamy stopień pewności, który odbiera nam zdolność do dziwienia się, tłumi umiejętność dostrzegania innych interpretacji i nowych możliwości działania (...). Dlatego właśnie bronimy się przed atakiem na nasze przekonania z taką siłą, jak gdyby chodziło o atak na nas samych"19.

W filarze struktury uniwersytetu jako organizacji uczącej się są także teorie, metody i narzędzia. Mają one służyć rozwojowi aspiracji, refleksji i konceptualizacji - w interesującym nas zakresie - w obszarze rozwiązywania sporów. Także w tym obszarze zachodzą interakcje, które powinny podlegać monitorowaniu, bo metoda monitorowania pozwala na

17

Adaptuję w tym zakresie poglądy wyłożone w publikacji: D. Bohm, Wholeness and the Implicate Order, Routledge Classics, London-New York 2002.

8 Na temat relacji i zarządzania nimi zobacz szerzej: R. Tyszkiewicz, Zarzadzanie relacjami z interesariuszami organizacji, Wydawnictwo Placet, Warszawa 2017.

P. Senge, Iść naprzód. Strategiczne myślenie o budowaniu organizacji uczących się, w: P. Senge, A. Kleiner, Ch. Roberts, R. B. Ross, B.J. Smith, Piata Dyscyplina. Materiaty dla praktyka, Wolters Kluwer, Warszawa 2013, s. 44. 
unikanie zagrożeń. Dla przykładu autor Piątej Dyscypliny podaje, że teoria o funkcjonowaniu układu krążenia doprowadziła do opracowania metody monitoringu krążenia, a w efekcie pozwoliła uniknąć zagrożeń płynących z nieregularności akcji serca. Podobnie jest na uniwersytecie, gdzie monitorowanie pewnych schematów zachowań i wczesna „diagnoza symptomów" konfliktu może doprowadzić do uniknięcia ich eskalacji, a niekiedy być może rozwiązania problemu na jego przedpolu lub we wczesnej fazie $^{20}$. Schemat może działać także w drugą stronę. Wprowadzenie pewnych praktycznych narzędzi może poprzez obserwację ich działania doprowadzić do konceptualizacji teorii. Porządkowanie doświadczenia płynącego z nierozwiązanych, jak i rozwiązanych konfliktów będzie zwrotnie budowało teorię i podstawę dla przyszłych narzędzi ${ }^{21}$. W organizmie, jakim jest uniwersytet, nie wystarczą jednak narzędzia statyczne. Prosty schemat przyczyna - efekt, jak mogłoby się wydawać na podstawie diagramu Ishykawy ${ }^{22}$, może okazać się niewystarczający, gdyż jak wynika z badań porównawczych, pewne problemy są wynikiem cyrkularności schematów działania (schemat błędnego koła samospełniającego się przekonania). $\mathrm{Na}$ tym właśnie polega główna trudność opracowania metody i narzędzi ukierunkowanych docelowo na „zmiany myślenia” w obszarze rozwiązywania konfliktów.

Trzecim elementem schematu uniwersytetu jako organizacji uczącej się są innowacje w zakresie infrastruktury. Największe znaczenie w obszarze rozwiązywania konfliktów będą miały innowacje, które pozwalają rozwijać zdolności ludzkie w kontekście ich bieżących zadań zawodowych. Przestrzeń pracy ma stać się przestrzenią uczenia. Gdyby bowiem uczenie się rozwiązywania konfliktów pozostało elementem niepodlegającym stałemu wdrożeniu, wówczas mielibyśmy do czynienia „z jeszcze jednym szkoleniem”. Obszar praktyki i aktywnego stosowania nowych kompetencji wpływa na zbudowanie nowej jakości, czyli osiągnięcia celu organizacji uczącej się.

\footnotetext{
20 Por. Raport z badań w zakresie analizy komentarzy, pkt. 6.

21 A. Binsztok, P. Miłoszewski, Spory pracownicze. Rozwiazywanie i zapobieganie, Wydawnictwo Marina Wrocław 2018.

22 Por. M. Mróz, Diagram Ishikawy. Sposób na rozwiązanie problemu, Wydawnictwo 2K Consulting Krzysztof Kowal, Łódź 2019.
} 
Rys. 3. Grafika przedstawia układ współrzędnych ${ }^{23}$.

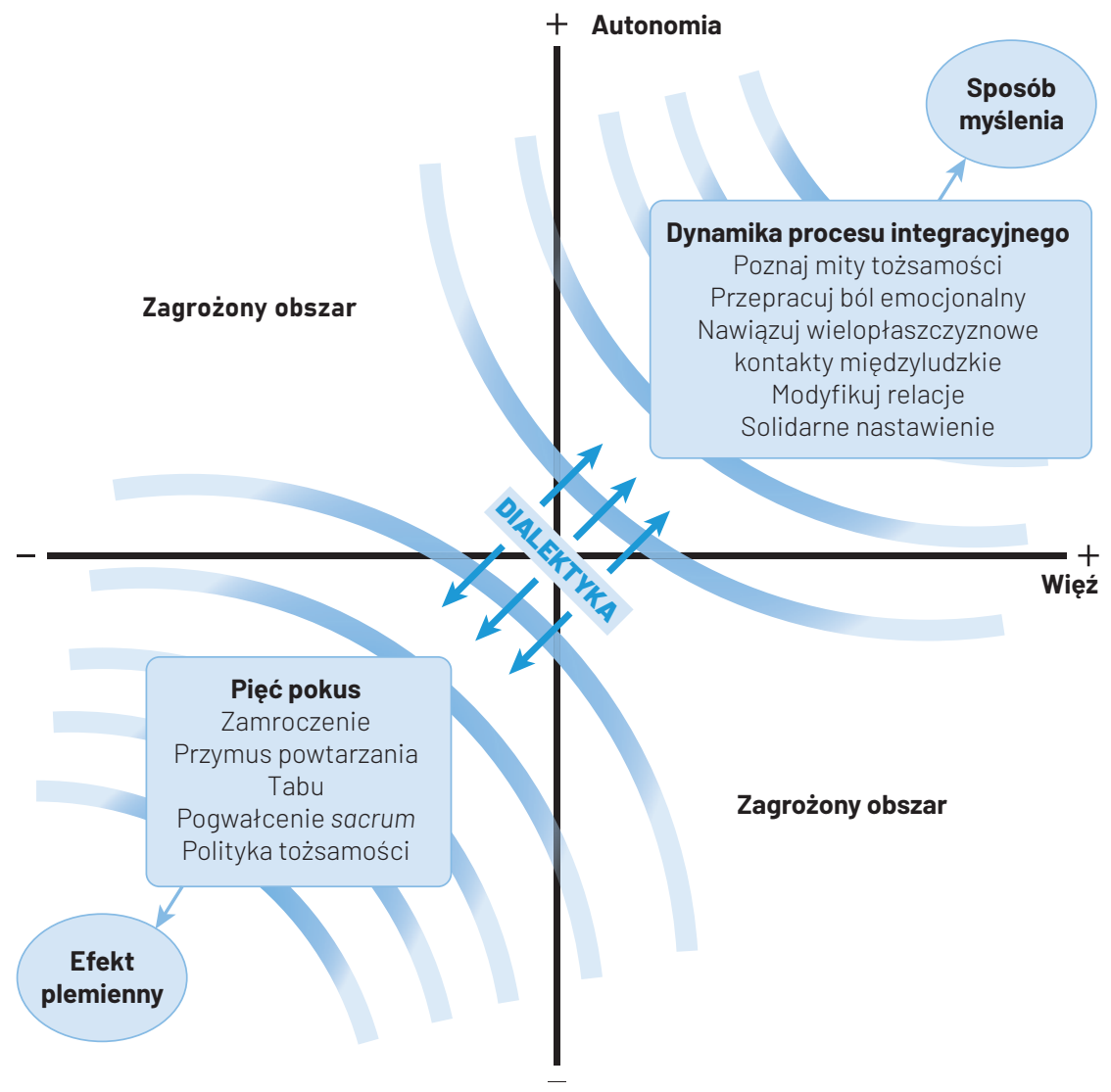

Rysunekzaczerpnięty z opisu koncepcji organizacji uczącej się, opracowanej przez Petera M. Senge, przypis z literatury.

23 Oś pionowa nazwana jest „autonomią” a oś pozioma nazwana jest „więzią”. Lewy dolny róg między osiami nazwany jest „efektem plemiennym” a prawy górny róg między osiami nazwany jest „sposobem myślenia”. Lewy górny róg między osiami oraz prawy dolny róg między osiami obrazują obszary zagrożone. Skrzyżowanie osi nazwane jest „dialektyką”. Przejście z lewego dolnego rogu - efektu plemiennego do prawego górnego rogu - sposobu myślenia - wymaga procesu intelektualnego odejścia od tzw. pięciu elementów plemiennych: zamroczenia, przymusu powtarzania, tabu, pogwałcenia sacrum, polityki tożsamości i przejścia do elementu, w którym myślenie jest zmodyfikowane (prawy górny róg), przy czym modyfikacja myślenia dotyczy elementów: poznania mitów tożsamości, przepracowania bólu emocjonalnego, nawiązania, zbudowania lub zmodyfikowania relacji oraz przyjęcia, wspólnego, solidarnego nastawienia. Przesuwanie się wzdłuż każdej z osi oznacza poziom intensywności. 
Połączenie elementów zobrazowanych schematem koła i trójkąta pozwala ukształtować schemat modelu uniwersytetu jako organizacji uczącej się. Bez idei przewodnich nie ma zaangażowania. Bez teorii, narzędzi, metod trudniej jest osiągnąć postęp w głębokim uczeniu się. Bez innowacji trudno ustabilizować myślenie ukierunkowane na przyszłość, zbudować wiarygodność na miarę wyzwań społecznych, które z sobą przyniósł XXI wiek. Szybkie zmiany strukturalne mogą budzić samoistny opór, stąd niezbędne jest przygotowanie podłoża, w ramach którego będzie wprowadzany w życie model organizacji uczącej się. Możliwym schematem jest wydzielenie obszaru do pilotproject (co może wydłużyć okres wprowadzania zmian) lub rozpoczęcie zmian od tych obszarów struktury uniwersytetu, w których dotychczas kumulowały się procesy konfliktowe. Jeżeli na tym podłożu osiągnie się wstępne zrozumienie projektu, to istotne będzie przeniesienie modelu na strukturę całego uniwersytetu, a może raczej nazwanie i nadanie znaczenia nowemu modelowi pracy $z$ konfliktem. W efekcie oddolną metodą możliwe będzie uzyskanie zmiany w strukturze całej organizacji.

\section{Mapa uniwersytetu - jak jest}

Na wczesnym etapie realizacji projektu badawczego dokonano „zmapowania” aktualnego stanu organizacyjnego i metod rozwiązywania konfliktów. Konkluzja nie napawała optymizmem. Zasadniczo Uniwersytet Jagielloński ma w swojej strukturze jednostkę, która zgodnie ze swoim regulaminem zajmuje się zarówno pracą naukowo badawczą, dydaktyką, jak i rozwiązywaniem konfliktów. Zgodnie z regulaminem Centrum Alternatywnego Rozwiązywania Sporów Uniwersytetu Jagiellońskiego \$2 ust. 1 „Zadaniem Centrum jest inicjowanie, organizowanie i koordynowanie różnorakich form aktywności naukowej, w tym przede wszystkim badawczej, w zakresie analiz różnych możliwości rozwiązywania sporów przez prawo. Ponadto funkcją Centrum jest koordynowanie i wzbogacanie oferty dydaktycznej Uniwersytetu oraz praktyczne wykorzystywanie alternatywnych metod rozwiązywania sporów”. Praktyka korzystania z działalności tej jednostki jest jak dotąd skromna.

Jak się wydaje, uniwersytet jak dotychczas preferował realizację zadań w obszarze konfliktów przez przypisanie lub wykluczenie odpowiedzialności (rektor, rzecznicy dyscyplinarni, komisje dyscyplinarne, komisje doraźne dla 
spraw własności intelektualnej, komisje do spraw mobbingu), lub też przez technikę przeczekania, a niekiedy przemilczenia. Równolegle do takiej preferencji widoczne stało się zjawisko odzwierciedlające postawę studentów uczestniczących w konflikcie. Cykliczność okresów studiów powoduje, że studenci we wczesnej fazie konfliktu obawiają się go ujawnić, a w okolicach sesji „wolą przeczekać” w nadziei, że przetrzymają, a potem problem nie jest już „ich” problemem. Stan taki nie odpowiada oczekiwaniom społeczności studenckiej sensu largo, nie wspiera pracowników, którzy borykają się z różnymi wyzwaniami związanymi z konfliktami w grupach czy zespołach badawczych, ale także nie wspomaga w kreowaniu wizerunku uniwersytetu. Także istnienie aż pięciu związków zawodowych w obszarze struktury uniwersytetu jest odzwierciedleniem nie tylko jego wielości, ale także dynamiki procesów pracowniczych, domagających się stałej reprezentacji interesów, także w zakresie spraw rodzących konflikty.

Bardzo istotnym elementem, który może wpływać na ograniczone znaczenie Centrum Alternatywnego Rozwiązywania Sporów Uniwersytetu Jagiellońskiego w zakresie efektywnego wspierania uczelni w rozwiązywaniu sporów, jest zbyt silna konotacja metod jego działania z pojęciem prawa, jakoby nie obejmującego metod polubownego rozwiązywania sporów. Oczywiście jest to przekonanie błędne, ale powszechne. Dla przykładu mediacja jest postrzegana jako forma odejścia od prawa, co także jest przekonaniem fałszywym, nawet jeśli prawdą jest, że celem mediacji nie jest ustalenie tego, jakie byłoby najbardziej prawdopodobne rozstrzygnięcie sądu. Celem mediacji jest bowiem rozwiązanie sporu w oparciu o interesy stron ${ }^{24}$. W praktyce oznacza to wypracowanie punktu, w którym strony chcą się spotkać $\mathrm{z}$,ich powodów”, a nie z takiego, który obiektywnie i racjonalnie mógłby zostać uznany za właściwy (oczywiście w wielu wypadkach są to punkty tożsame, ale są jednak także i takie ugody, które umykają kryterium obiektywności). Dodatkowo nieformalność procesu mediowania i jego poufność sprawiają, że instytucja ta nie jest dostatecznie wypromowana w świadomości interesariuszy uczelni. Podkreślenie normatywnego charakteru rozwiązania wypracowanego w mediacji jest elementem szalenie istotnym i odpowiada

24 Na temat mediacji: A. Zienkiewicz, Studium mediacji. Od teorii ku praktyce, Difin, Warszawa 2007; J. Czapska, M. Szeląg-Dylewski, Mediacje w prawie, Wydawnictwo Uniwersytetu Jagiellońskiego, Kraków 2014; K. Płeszka, J. Czapska, M. Araszkiewicz, M. Pękala, Mediacja. Teoria, normy, praktyka, Wolters Kluwer, Warszawa 2017; E. Gmurzyńska R. Morek, Mediacja. Teoria i Prakty$k a$, Wolters Kluwer, Warszawa 2018. 
naturze skutecznego, stabilnego i oczekiwanego rozwiązania wypracowywanego przez strony z udziałem neutralnej osoby trzeciej, a ostatecznie opartego o działania prowadzone na podstawie prawa i w zgodzie $\mathrm{z}$ prawem ${ }^{25}$. Udział neutralnego pośrednika (mediatora, osoby zaufanej, ale też bezstronnej) pozwala zmniejszyć dystans między stronami związany z hierarchicznością stosunków, nierównowagą strukturalną, niechęcią, uprzedzeniami i urażoną dumą.

Wzmocniona promocja informacji w ramach uniwersytetu o sposobach rozwiązania konfliktów lub samej działalności Centrum Alternatywnego Rozwiązywania Sporów Uniwersytetu Jagiellońskiego, ewentualnie projektów takich jak Uniwersytecka Przestrzeń Dialogu oraz zezwolenie na częściowe odformalizowanie procedur, sprzyjałoby budowaniu schematów wspierających elastyczność w podejściu do rozwiązania konfliktu w oparciu o interesy stron, a nie w oparciu o relacje transakcyjne (przyczyna - skutek).

\section{Wybór metody}

Odnośnie metody rozwiązywania konfliktów, należy podkreślić znaczenie ich wielości i elastyczności. Zgodnie ze słowami przypisywanymi Markowi Twainowi: „Jeżeli ma się tylko młotek, to każdy problem będzie wyglądał jak gwóźdź”. Na uczelniach istnieje wiele typów konfliktów, o bardzo różnej dynamice i strukturze. Nawet wstępne badania pokazują, że niezbędna jest elastyczność, poufność i bardzo dobra promocja wiedzy o metodach rozwiązywania konfliktów ${ }^{26}$. Palący wydaje się problem stworzenia grupy ambasadorów mediacji, rozumianych nie jako sformalizowana jednostka, ale jako grupa osób - nośników informacji o znaczeniu osoby neutralnej w spojrzeniu na konflikt, zredefiniowaniu problemów w sporze, nazwaniu ich i wsparciu w wypracowaniu rozwiązań kończących spór. Zagadnienie to zostanie opracowane w przyszłym projekcie wykonawczym badań.

25 Ogólnie o potrzebie kształcenia prawników w zakresie umiejętności miękkich, jak również o technikach: A. Jakubiak Mirończuk, Negocjacje dla prawników. Prawo cywilne, Lex Wolters a Kluwer business, Warszawa 2010; M. Tabernacka, Negocjacje i mediacje $w$ sferze publicznej, Wolters Kluwer, Warszawa 2018; J. Stelmach, Sztuka manipulacji, Wolters Kluwer, Warszawa 2018; J. Jabłońska-Bonca, K. Zeidler, Prawnik a sztuka retoryki i negocjacji, Wolters Kluwer, Warszawa 2016.

26 Odwołuje się w tym zakresie do praktycznych refleksji dotyczących jednej z metod, ale ukazujących spektrum możliwych innych rozwiązań. M. Pel, Referral to mediation. A practical guide for an effective proposal, SDU UITGEVERS, The Hague 2008. 
Rys. 4. Schemat różnicy w rozumowaniu

\section{NEGATYWY}

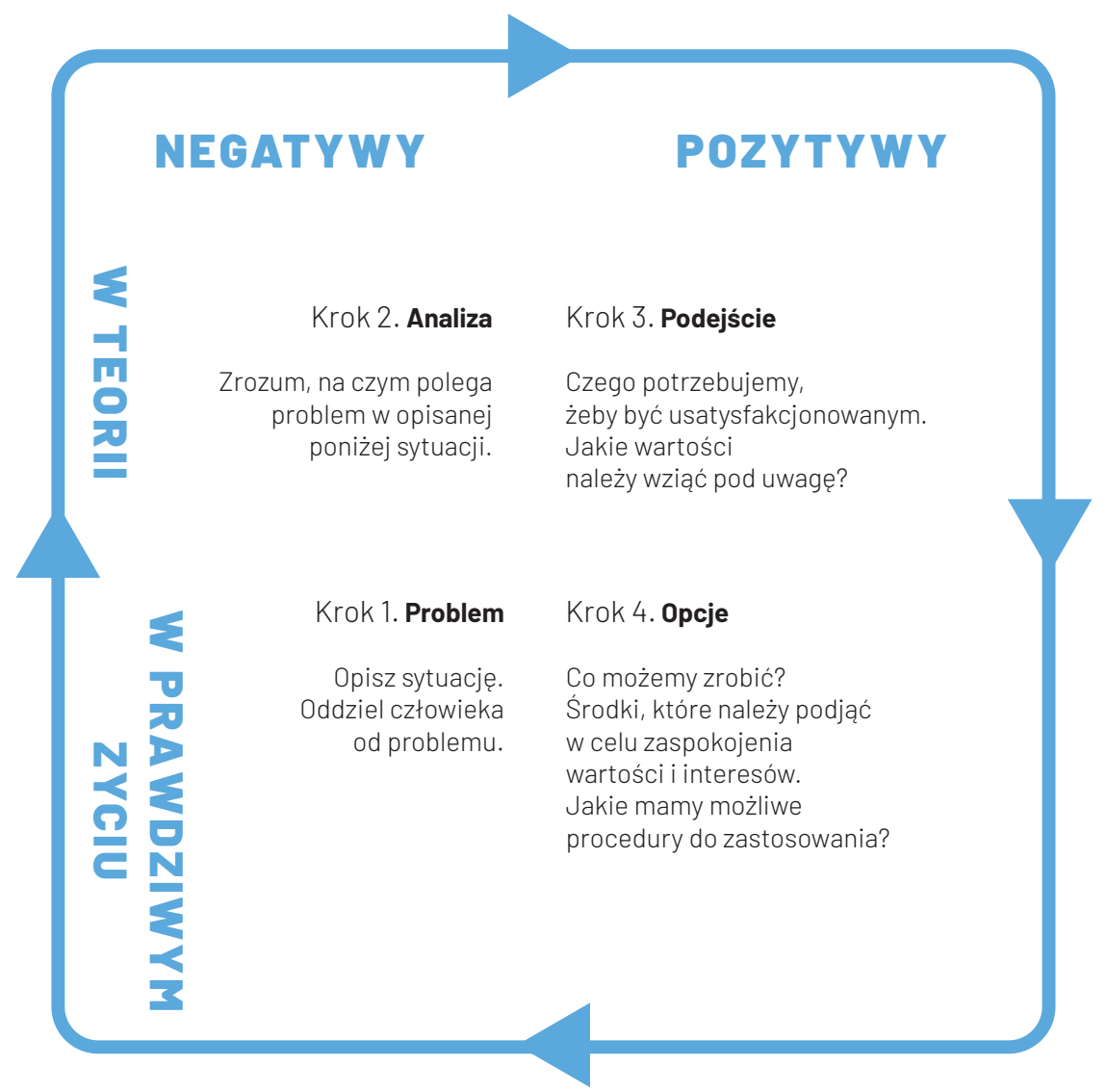

Koncepcja zaczerpnięta z opracowania Thierreg Garby Agreed! Negotiation/mediation in the 21st century, International Chamber of Commerce 2015.

Rozważając kwestię tego, na jakie elementy metody należy zwrócić przy rozwiązywaniu konfliktów w ramach uniwersytetu, podkreślić należy, że istotą jest osiągnięcie stanu „pokoju” przy optymalnym poziomie zaspokojenia interesów stron znajdujących się w konflikcie. Rozwiązanie konfliktu nie będzie więc polegało na przeprowadzeniu „dochodzenia”, kto, kiedy i dlaczego „zepsuł” relacje. Zakłada się bowiem, że wszystkie strony pracowały w dobrej wierze w celu zrealizowania zadań im powierzonych. Konflikt 
zaistniał z przyczyn, których ustalenie nie zawsze ma pierwszorzędne znaczenie. Oczywiście są sytuacje, gdy ustalenie przyczyn jest istotne dla rozwiązania, ale - jak wynika z badań - cyrkularność stanów konfliktowych może pozbawiać takie ustalenia znaczenia.

\section{Wnioski}

Uniwersytet jako organizacja ucząca się w dziedzinie rozwiązywania konfliktów może rozważyć zbudowanie mapy zmian w poszczególnych obszarach. Aby wypełnić kryteria stawiane uczelni badawczej, współpracującej na płaszczyźnie międzynarodowej, interdyscyplinarnej, innowacyjnej i spójnej, nie trzeba odkrywać koła. Można skorzystać z doświadczeń i wzorów już wypracowanych na uczelniach europejskich i amerykańskich oraz wzbogacić je wiedzą opartą na doświadczeniu na rodzimym gruncie. Warto uwzględniać kontekst kulturowy, który w kraju nad Wisłą jest szczególnie widoczny, a na uniwersytecie o blisko siedmiu wiekach tradycji - po prostu niezwykle ważny. Profesor Susan S. Raines z Kennesaw State University w USA, która w czasie badań była jedną z osób prezentującej model amerykański (znacznie krótszy kulturowo okres historii uniwersytetów przy intensywnym rozwoju szkół wyższych zawodowych, czy wręcz biznesowych), zadała w dyskusji ważne pytanie: What make you diffrent? Konfrontując się z tym pytaniem w czasie badań, obserwacji i formułowania wniosków, warto sięgnąć do wskazań ekspertów z najwyższej półki. Specjaliści od negocjacji i konfliktów wskazują w tym obszarze na konieczność skonfrontowania się z oporem w strukturze uniwersytetu, który można zdefiniować jako „idzie nowe”, ale także z kulturą organizacji, która tworzy własne mity, w tym mity nazywane „plemiennymi”.

Według Daniela L. Shapiro ${ }^{27}$ pięć pokus plemiennego rozumowania to:

- zamroczenie - to wypaczony stan świadomości, w którym relacja prowadzi do wyczerpania energii emocjonalnej; w przypadku uniwersytetu może to być ukształtowanie poglądu „zawsze było inaczej” (np. nie było jednostki od wsparcia rozwiązywania konfliktów), bez wejścia w głębszą dyskusję na temat tego, jakie ratio stało za pierwotnym wzorem;

27 Por. D. L. Shapiro, Negocjuj nienegocjowalne..., dz. cyt., s. 30. 
- przymus powtarzania - to wzorzec samoobrony, w którym kompulsywnie powiela się te same argumenty;

- tabu - to „zakazy” społeczne utrudniające relacje oparte na współpracy;

- pogwałcenie sacrum - to atak na najważniejsze filary tożsamości;

- polityka tożsamości - to manipulowanie tożsamością zmierzające do realizacji celów politycznych przeciwnika.

Do zbudowania struktury wczesnego wykrywania i monitorowania sporów niezbędne wydaje się zwiększenie działań informacyjnych, edukacyjnych i monitorujących. Biorąc pod uwagę, że detektowanie konfliktów połączone jest z obawami o „rezonans” środowiskowy, warto rozważyć co najmniej cztery elementy architektury projektu:

- kanał przyjmowania zgłoszeń, którego struktura powinna zapewnić obsługiwanie zgłoszeń w sposób zapewniający nieujawnianie tożsamości osoby zgłaszającej oraz uniemożliwiający dotarcie podmiotu objętego „zarzutem” bezpośrednio do zgłoszenia w celu wyeliminowania działań odwetowych. Nie chodzi przy tym o „naruszenie prawa do obrony," ale umożliwienie neutralnej i obiektywnej oceny sytuacji bez zbyt wczesnego konfrontowania stron;

- precyzyjne, powszechne i łatwo dostępne informacje o procedurach oraz sposobie, warunkach i możliwości rozwiązania konfliktu w ramach procedur wewnętrznych i zewnętrznych;

- wyznaczenie osób zaufania czy rzeczników mediacji na różnych szczeblach struktury uniwersytetu, także w ramach różnych jednostek, właściwych do podejmowania działań z należytym rozeznaniem, starannością i poufnością. Także w tym wypadku nie chodzi o sformalizowanie procedury, zawieranie umowy o mediację i strukturyzowanie procesu. Istotą jest wejście podmiotu neutralnego pomiędzy strony konfliktu i rozważenia, jakie potencjalnie kroki, drogi nieformalne i formalne, można podjąć, by strony dostrzegły konflikt w szerszej perspektywie i same rozważyły metody wyjścia z niego;

- ustalenie rozsądnego terminu przekazania informacji zwrotnej zgłaszającemu o podjętych krokach i działaniach, także z możliwością przedstawienia opcji lub mapy drogowej rozwiązania konfliktu.

W działalności prawników szczególnie ważny będzie mit, który głosi, że przepis prawny jest odpowiedzią na wszystko. To twierdzenie nie wytrzymuje 
konfrontacji z praktyką. Nawet Komisja Europejska - dostrzegając trudności, jakie napotykają prawnicy w mediacji i dialogu, a także w stosowaniu metod alternatywnych w rozstrzyganiu sporów - sformułowała już w 2009 roku Concept on Strengthening UE Mediation and Dialouge Capacities (Dokument Z 10.11.2009 roku 15779/o9), natomiast w roku $2018 \mathrm{w}$ ramach projektu Efficiency of Justice Komisja Europejska stworzyła cały zestaw narzędzi dla prawników: „Zestaw narzędzi do doskonalenia mediacji zapewniający wdrożenie wytycznych CEPEJ w sprawie mediacji” (Mediation Development Toolkit. Ensuring implementation of the CEPEJ Guidelines on mediation CEPEJ 2018/7 z dnia 27.06.2018). Materiały zawarte w tym dokumencie skierowane były do sędziów, pracowników sądów, mediatorów, centrów mediacji, prawników i uczestników mediacji.

Uniwersytet powinien zmierzać do maksymalizacji wsparcia merytorycznego w konflikcie, w taki jednak sposób, by jego uczestnicy sami - lub z pomocą osoby neutralnej, a niekiedy organu - mogli wypracować rozwiązanie. Ta pomoc w nawigacji konfliktem wzmacnia poczucie własnej wartości, ale także rodzi odpowiedzialność za przyjęte rozwiązanie i wolę umacniania jego efektów, a także podejmowania działań prewencyjnych przy dostrzeganych nawrotach objawów. Tym samym jest naturalnym powodem zmniejszania się liczby konfliktów w przyszłości.

Bazując na doświadczeniach kolegów z uniwersytetów w innych krajach, wszystkie osoby działające w ramach jednostek zajmujących się rozwiązywaniem konfliktów skupiają się na:

- słuchaniu i wzmacnianiu (empower) - pomagają zidentyfikować cele i rozwinąć plan działania dla ich realizacji;

- wspieraniu procesu komunikacji i zrozumienia postawy drugiej strony konfliktu - umożliwiają dialog, który ma modyfikować sposób postrzegania i prowadzić do zrozumienia drugiej strony; istotne w tym procesie jest odkrycie rzeczywistych interesów stron (niekiedy ukrytych pod pozorami), a nie tylko werbalizowanych żądań;

- prowadzeniu niezależnego monitoringu zjawisk i relacji w ramach uniwersytetu i adresowaniu spostrzeżeń dla ułatwienia wczesnych procesów decyzyjnych. 


\section{Uwagi dodatkowe}

Ważne jest także wyposażenie jednostki uniwersyteckiej zajmującej się rozwiązywaniem konfliktów w takie atrybuty, które usuną z jednej strony obawy stron konfliktu co do „sprzyjania” władzom, a z drugiej strony na tyle usamodzielnią jednostkę, aby osoby działające w jej ramach nie stały się dla władz uniwersytetu „wrogami numer jeden” z uwagi na próby wsparcia czy wypracowania rozwiązań, które nie do końca są zgodne z przekonaniami decydentów. Natura jednak postępowań polubownych opiera się na wzajemnych ustępstwach. Specjaliści zwykli mawiać, że dobra ugoda to taka, z której obie strony są niezadowolone, gdyż musiały z czegoś zrezygnować, jednakże rezygnacja w tego „czegoś” była per saldo korzystna z uwagi na zakończenie sporu i osiągnięcie sytuacji „pokoju”.

Do podstawowych atrybutów należą:

- niezależność - w zakresie struktury, funkcji i możliwości dialogu nawet z najwyższym poziomem organizacyjnym uniwersytetu;

- neutralność i bezstronność - pozwalają obu stronom zbudować zaufanie do jednostki oraz pokładać wiarę, że sugestie czy proponowane kroki nie będą pogarszały sytuacji żadnej ze stron;

- poufność - tak dalece posunięta, że - poza wypadkami ryzyka nieuniknionej i bezpośredniej szkody na osobie lub poważnej szkody na mieniu - informacje powierzone jednostce pozostają w dyspozycji stron konfliktu, bez prawa ujawniania ich na zewnątrz;

- nieformalność i elastyczność procedur - pozwalają na dobranie narzędzi i metod rozwiązania konfliktu w sposób odpowiedni dla ich natury.

\section{Budowanie strategii}

Aby przygotować strategiczne rozwiązania w zakresie rozwiązywania konfliktów uczelnianych, niezbędne jest podjęcie decyzji kierunkowych w poniższych obszarach ${ }^{28}$ :

28 Opracowano na podstawie kwestionariusza sporządzonego w 2015 roku przez Office of the Independent Adjudicator for Higher Education (OIA) organu statutowego zajmującego się badaniem skarg studenckich w Anglii i Walii, który to podmiot jest pełnoprawnym członkiem Europejskiej Sieci Ombudsmanów w Szkołach Wyższych (ENOHE) 
- Czy model rozwiązywania konfliktów oparty będzie na podmiocie wewnątrz struktury uniwersyteckiej, czy też poza jej strukturą? (Poszukiwanie podstawy w prawie powszechnie obowiązującym, $\mathrm{w}$ aktach wewnętrznych uczelni, ewentualnie w porozumieniu międzyuczelnianym); na konkretnym wydziale, czy jako jednostka międzywydziałowa, ogólnouniwersytecka?

- Czy model rozwiązywania konfliktów oparty będzie na jednym podmiocie nowo utworzonym (wg modelu Conflict Advisory Service, Conflict Management Servis, Dispute Resolution Center, Instytut for Conflict Management), grupie powiązanych struktur, czy będzie oparty na już istniejących elementach organizacyjnych (rzecznik wartości akademickich, Centrum Alternatywnego Rozwiązywania Sporów Uniwersytetu Jagiellońskiego) odpowiednio zmodyfikowanych?

- Czy działalność podmiotu zajmującego się rozwiązywaniem konfliktów lub ułatwianiem ich rozwiązania będzie strukturalnie powiązana z organizacją struktur, które odpowiedzialne są za ustalanie deliktów dyscyplinarnych, czy wymierzaniem odpowiedzialności za popełnione czyny (np. w ramach procedur mobbingowych, antyplagiatowych)?

- Czy istnieją środki i zostaną podjęte działania w obszarze edukacyjnym i promocyjnym w zakresie metod rozwiązywania sporów i budowania przestrzeni dialogu?

- Jaki będzie model wybierania osoby/organu zarządzającego konfliktami akademickimi: otwarta zewnętrzna procedura konkursowa, wewnętrzna procedura konkursowa, wybory wewnątrz uczelni, nominacja senatu lub rektora, kombinacja wskazanych czy inne niewymienione?

- Czy praca wskazanej osoby zarządzającej/organu będzie miała wymiar etatu, czy będzie traktowana jako funkcja/dodatkowe zajęcie w ramach zatrudnienia?

- Czy funkcja będzie kadencyjna, czy też powołanie bezterminowe, z możliwością odwołania z funkcji w każdej chwili?

- Czy funkcja będzie mogła być łączona z innymi funkcjami na uniwersytecie (poza obowiązkami dydaktycznymi)?

- Jakie będą główne obowiązki/uprawnienia i metody działań osoby/ organu? (osoba zaufana „wysłuchująca”, interest based facilitator, koncyliator, neutralny doradca, arbiter w sporach, mediator - neutralny 
pośrednik, informator, ewaluator, „agent zmiany”, reprezentant strony, rzecznik interesu publicznego - ombudsman), kombinacja powyższych lub inne?

- Czy możliwe będzie podjęcie się sprawy na podstawie własnych ustaleń, czy niezbędny będzie wniosek formalny strony lub podmiotu trzeciego (niezaangażowanego w konflikt)?

- Czy w przypadku konieczności złożenia wniosku formalnego, który mimo konfliktu nie jest składany, możliwe będą inne działania negocjacyjne, koncyliacyjne?

- Jakie zasady będą kreowały pozycję podmiotu zarządzającego konfliktem: niezależność, neutralność i bezstronność, poufność, formalność czy nieformalność postępowania/działań, kombinacja jednej, kilku lub wszystkich elementów/cech?

- Czy podmiot zarządzający konfliktem będzie mógł proponować rekomendacje, zalecenia, formułować wskazania dobrych praktyk, niewiążące lub wiążące?

- Czy podmiot zarządzający konfliktem będzie mógł monitorować wykonanie rekomendowanych wskazań formalnych lub nieformalnych?

- Czy podmiot zarządzający konfliktem będzie miał prawo do uzyskania informacji od organów, jednostek, pracowników uczelni i wykorzystać je zgodnie z zasadami poufności lub jawności?

- Czy podmiot zarządzający konfliktem będzie wyposażony w środki, które pozwolą na realizację zadań (budżet wydzielany rocznie/okresowo, pomieszczenia lub dostępność infrastruktury, czy też będzie podlegał innej jednostce/organowi)?

- Czy podmiot zarządzający konfliktem będzie mógł prowadzić szkolenia? Jeśli tak, to: $\mathrm{W}$ jakiej formie? W jakim zakresie? W jakim wymiarze czasowym? Zasobami własnymi czy przy użyciu środków zewnętrznych?

- Czy będzie obowiązany do sporządzania raportów okresowych (statystycznych lub merytorycznych) i czy będą one dostępne społeczności akademickiej (publikowane na stronach WWW).

Uniwersytet spełnia kryteria organizacji uczącej się. Możliwe jest wdrożenie na uniwersytecie planu realizacji „uczenia się" w obszarze rozwiązywania konfliktów w społeczności akademickiej liczącej ponad 30 ooo członków. 


\section{Bibliografia}

1. Binsztok A., Miłoszewski P., Spory pracownicze. Rozwiazywanie izapobieganie, Wydawnictwo Marina, Wrocław 2018.

2. Bohm D., Wholeness and the Implicate Order, Routledge Classics London, New York 2002.

3. Cameron K.S., Quinn R.E., Kultura organizacyjna - diagnoza izmiana. Model wartości konkurujących, wydanie 2, Wolters Kluwer, Warszawa 2015.

4. Czapska J., Szeląg-Dylewski M., Mediacje w prawie, Wydawnictwo Uniwersytetu Jagiellońskiego, Kraków 2014.

5. Friedman G., Himmelstein J., Challenging Conflict. Mediation Through Understanding, ABA Section of Dispute Resolution 2008.

6. Gmurzyńska E., Morek R., Mediacja. Teoria i Praktyka, Wolters Kluwer, Warszawa 2018.

7. Haman W., Gut J., Zrozumieć zespót. Fenomen matej grupy. Jak radzić sobie z trudnymi zrachowaniami zespotu, a zwłaszcza z narzekaniem i marudzeniem, Kontakt OSH Grupa Szkoleniowa, Warszawa 2019.

8. Jabłońska-Bonca J., Zeidler K., Prawnik a sztuka retoryki i negocjacji, Seria Akademicka, Wolters Kluwer, Warszawa 2016.

9. Jakubiak Mirończuk A., Negocjacje dla prawników. Prawo cywilne, Lex Wolters a Kluwer business, Warszawa 2010.

10. Kaszowy M., Strategie retoryczne, techniki komunikacyjno-poznawcze, btędy i sofizmaty, Wydawnictwo IFIS PAN, Warszawa 2015.

11. Loeffler M., AGILE. Retrospektywy w zarzadzaniu standardami, Wydawnictwo Helion, Gliwice 2018.

12. Mróz M., Diagram Ishikawy. Sposób na rozwiązanie problemu, Wydawnictwo $2 \mathrm{~K}$ Consulting Krzysztof Kowal, Łódź 2019.

13. Neale S., Spencer-Arnell L., Wilson L., Coaching inteligencji emocjonalnej, Wolters Kluwer, Warszawa 2018.

14. Nikodemska S., Assessment Development Center. Projektowanie procesu i narzędzi oceny, INFOR, Warszawa 2018.

15. Nikolopoulos A., Negotiating Strategically. One Versus All, Palgrave Macmillan Andreas Nikolopoulos 2011.

16. Obłój K., Praktyka strategii firmy. Jak zarządzać przeszłościa, radzić sobie z teraźniejszością i tworzyć przyszłość, Wydawnictwo Poltex, Warszawa 2020. 
17. Pel M., Referral to mediation. A practical guide for an effective proposal, SDU UITGEVERS, The Hague 2008.

18. Płeszka K., Czapska J., Araszkiewicz M., Pękala M., Mediacja. Teoria, normy, praktyka, Wolters Kluwer, Warszawa 2017.

19. Prusak A., Stefanów P., AHP - analityczny proces hierarchiczny. Budowa i analiza modeli decyzyjnych krok po kroku, Wydawnictwo C. H. Beck, Warszawa 2014.

20. Schein E.H., Schein P.A., Potega relacji w zarzadzaniu. O trudnej sztuce bycia pokornym liderem, Wydawnictwo Naukowe PWN, Warszawa 2019.

21. Senge P.M., Kleiner A., Roberts Ch., Ross R. B., Smith J. B., Piata dyscyplina. Materiaty dla praktyka, Wolters Kluwer, Warszawa 2013.

22. Shapiro D. L., Negocjuj nienegocjowalne. Jak rozwiazywać konflikty podszyte emocjami?, Harvard Business Review Polska 2019.

23. Stelmach J., Sztuka manipulacji, Wolters Kluwer, Warszawa 2018.

24. Stelmach J., Brożek B., Negocjacje. Jak negocjowaćw sposób stuszny, skuteczny i ekonomicznie efektywny?, Copernicus Center Press 2019

25. Tabernacka M., Negocjacje i mediacje w sferze publicznej, Wolters Kluwer, Warszawa 2018.

26. Tkaczyk P., Narratologia, Wydawnictwo Naukowe PWN, Warszawa 2017.

27. Tyszkiewicz R., Zarzadzanie relacjami z interesariuszami organizacji, Wydawnictwo Placet, Warszawa 2017.

28. Zawadzka A.M., Psychologia zarzadzania w organizacji, Wydawnictwo Naukowe PWN, Warszawa 2010.

29. Zienkiewicz A., Studium mediacji. Od teorii ku praktyce, Difin, Warszawa 2007. 